\title{
Eco-tourism, Conservancies and Sustainable Development: The Case of Zimbabwe
}

\author{
Victor Ngonidzashe Muzvidziwa \\ School of Social Sciences, University of KwaZulu-Natal, Durban, \\ KwaZulu-Natal, South Africa \\ E-mail: Muzvidziwa@ukzn.ac.za
}

KEYWORDS Eco-tourism. Conservancies. Conservation. Sustainable Development. Community

\begin{abstract}
The paper presents a definition of eco-tourism that puts an emphasis on conservation through utilisation, instead of an emphasis on preservation only. Eco-tourism in this paper is seen as incorporating both consumptive and non-consumption aspects. It is a definition that stresses community participation in decision making processes in relation to eco-touristic ventures and subsequent benefits derived from such ventures flowing back to local communities. The paper examines the triple role of eco-tourism in the protection, utilisation and conservation of natural and cultural resources. Tourism is by far a sector that continues to play a positive socioeconomic role in the midst of a declining economic base in the Zimbabwe of the post 2000 period. The paper views conservancies as tenurial units and goes further to examine the link between conservancies and eco-touristic ventures. The issue of sustainable eco-tourism developments in the form of conservancies is debated in the paper in the light of the socio-economic challenges Zimbabwe is going through. It is strongly argued that to avoid another case of entrenched failed development, conservancies need to be seen in a holistic manner that takes into account the role of all stakeholders or actors including the role of local communities.
\end{abstract}

\section{INTRODUCTION}

The Southern Africa Development Community (SADC) Protocol on Wildlife Conservation and Law Enforcement (1999) observes that conservation and sustainable use of wildlife resources in the region will stimulate sustainable economic development and conservation of biological diversity. Two of the seven objectives of the SADC Protocol specifically talk of the need to 1 . Promote sustainable use of wildlife; and to 2 . Facilitate community-based natural resources management practices for management of wildlife resources. Wildlife continues to be one of the drivers of Zimbabwe's touristic efforts, despite the harm caused by Zimbabwe's post-2000 chaotic land invasions. Tourism is one of the most important economic sectors in Zimbabwe. To some extend Gossling's (2000) observation with reference to Western countries that eco-tourism is the fastest growing component of the buoyant tourism sector seems equally true for Zimbabwe where everything has collapsed except tourism. Duff (2006) concurs that ecotourism is a rapidly growing tourism niche area. According to the UN (2008) World statistics country profile data, Zimbabwe is a low income country, had in 2008 an estimated population of 12463000 , with $36 \%$ of its population living on less that US\$1 per day. Tourist arrivals had de- clined for most of the previous decade in 2000 they were 1967000 and 1559000 in 2005 rising to 2508000 in 2008.

The Land Apportionment Act (1930) formalised the division of land along racial lines. The Act divided the land as follows:

Native Reserves

Native Purchase areas

European areas

Unassigned

Forest

29000000 acres 8000000 acres 9000000 acres 6000000 acres

3000000 acres

It is interesting to note that the land set apart as unassigned areas and protected areas (PAs) in the form of Parks and forests by the Land Apportionment Act (1930) has remained fairly intact and constitute approximately $16 \%$ of Zimbabwe's land. Much of this land is in semi-arid regions four and five. It is of limited use agriculturally but of high value in terms of wildlife carrying capacity. It has not been the subject of land invasions. Zimbabwe despite the chaotic land reform fast track programme is still well endowed with prime attractions in the form of wildlife and wilderness experience especially in the Protected Areas (PAs) for nature conservation. Wildlife populations and scenic attributes are considerable, within these PAs and outside them, on both communal and private land.

Most research on tourism in Southern Africa has focused on the perceptions of tourists (Mmopelwa et al. 2007), preferences of tourists 
(Chaminuka et al. 2011), travel motives of tourists (Saayman and Saayman 2009; van der Merwe and Saayman 2008) and tourists willingness to pay for wildlife viewing and wildlife conservation (Barnes et al. 1999). Eco-tourism especially in terms of the performance of conservancies has not received much attention. This paper challenges Western notions of eco-tourism that seek to privilege non-consumptive uses at the expense of consumptive use of touristic products like wildlife as found in conservancies. The paper also adopts Lashle et al.'s (2007) use of the social lens approach that enables us to understand and appreciate the dynamics of Zimbabwean society as seen through tourism and hospitality studies.

This paper is divided into four sections excluding the introduction and conclusion. The first section of the paper examines various ecotourism definitions and seeks to craft one that is appropriate to the SADC region. The second section presents a discussion of eco-tourism experiences in Zimbabwe. The third section presents a discussion of conservancies as eco-touristic vehicles. The fourth section preceding the conclusion links conservancies to sustainable development.

\section{DEFINING ECO-TOURISM}

The word eco-tourism hardly appears in Zimbabwe's official documents and speeches before 1998, but by 2000 it had become a buzzword in the country. This section first presents a set of definitions that have influenced how eco-tourism is perceived in Zimbabwe and to some extend SADC region. This has implications regarding the policies adopted in the area of tourism development. Eco-tourism covers a wide range of tourism activities, attractions and forms. ATEC cited by Mowforth and Munt (1998: 103) views eco-tourism as a constant struggle aimed at achieving a balance in terms of sustainable resource exploitation that also contributes to the well-being of local/host communities.

Björk (1997: 305) defines ecotourism as

An activity where the authorities, the tourism industry, tourists and local people cooperate to make it possible for tourists to travel to genuine areas in order to admire, study, and enjoy the nature and culture in a way that does not exploit the resources, but contributes to sustainable development.
Sirakaya et al. (1999: 171) observe that

Ecotourism is a new form of non-consumptive, educational, and romantic tourism to relatively undisturbed and under-visited areas of immense natural beauty, and cultural and historical importance for the purposes of understanding and appreciating the natural and socio-cultural history of the host destination.

For Weaver (2001: 15)

Ecotourism is a form of tourism that fosters learning experiences and appreciation of the natural environment, or some component thereof, within its associated cultural context. It has the appearance (in concert with best practice) of being environmentally and social-culturally sustainable, preferably in a way that enhances the natural and cultural resources base of the destination and promotes the viability of the operation.

To some extend eco-tourism is seen as a cooperative relationship involving tourists, host communities and the various stakeholders interested in eco-touristic activities. The eco-tourism experience is more enriching where tourists are more sincere, open minded, and approach their visits as learning and enjoyable experiences. Genuine and active community participation and control from the inception phase through implementation, monitoring and evaluation of an eco-tourism project is a must if the concept is to be successfully put into practice. Following this line of argument Wood cited in Mowforth and Munt (1998: 139) regards eco-tourism as "responsible travel to natural areas that conserves the environment and sustains the well-being of local people". Eco-tourism can thus be viewed as a responsible, sustainable, and environmentally sound form of tourism, which pursues a sound management and resource conservation strategy. In addition eco-tourism is also viewed as being culturally sensitive and seeks to reward those destinations that strive to uphold basic eco-tourism principles. Our understanding of the meaning of eco-tourism need to take into account Willis and Pangeti's (1998: 7) observation that eco-tourism "is a value loaded term. It attempts to balance economic benefits with environmentally sustainable use. It is concerned with maintaining both eco-systems and the needs of the local people. This implies an ethical stance". While in many instances ecotourism is used interchangeably with non-consumptive tourism, the situation in Zimbabwe and 
several other SADC countries calls for close reexamination of what constitute eco-tourism. Willis and Pangeti (1998: 7) make an interesting observation, which lead them to conclude, "If hunting is environmentally sustainable, surely it is an activity that promotes eco-tourism". The experience of Zimbabwe's Communal Areas Management Programme for Indigenous Resources (CAMPFIRE is the acronym for Zimbabwe's Communal Area Management Programme for Indigenous Resources). Rural District Councils (RDCs) show that where local communities are given proprietorship over wildlife resources, the need to conserve and to harvest the resources in an economically viable and sustainable manner becomes the norm. Controlled hunting is a key incentive to conserve and use wildlife resources in a sustainable manner. What is critical in qualifying an operation as an eco-tourist one or not hinges on whether the activity is environmentally sound, sustainable, adopts conservation strategies and ensures that benefits flow back to the local community. There is need for co-management and/or ownership of the resource by local communities and creation of environmental awareness amongst host communities, tourisiers, tourism professionals and workers, and tourists. In Zimbabwe eco-tourism includes hunting and photographic safaris, birding safari, game viewing, rock climbing, walking trails, cultural tours, viewing of 'bush men' paintings, etc. Eco-tourism embraces attractions and eco-experiences based on culture and nature. Hence not all hunting safari operations can be termed eco-tourist activities, only those whose benefits flow to host communities, are sustainable, controlled and ethical in nature are considered eco-tourist activities. Eco-tourism is specific and mainly focused on wildlife and other natural areas such as waterfalls and scenic sites. In addition to issues of preservation, sustainability, viability and equity issues eco-tourism puts a lot of emphasis on conservation and local participation and empowerment through sharing in benefits. Eco-tourist ventures need to focus on co-management and co-ownership of resources, creation of conservation and environmental awareness, provision of educational forum that highlights the long-term value of ecotourism. Zimbabwe through its unique wilderness and cultural experiences offered good ground for those in search of authenticity and authentic tourism experiences.
The distinction between consumptive and non-consumptive eco-tourism is rather artificial. All forms of eco-tourism have a consumptive dimension as people come to purchase an experience. The impacts of non-consumptive touristic uses could be harmful to the local cultural and physical environment. Meletis and Campbell (2007) argue that consumptive use should be considered an aspect of ecotourism provided such use is biologically feasible, socio-economically beneficial, and culturally appropriate and desirable. Consumptive use is possible and might even aid in achieving eco-tourism's dual goals of environmental and cultural conservation benefitting local communities and their environments. Consumptive ecotourism might be more in harmony with the socio-cultural contexts in which developments are taking place. Weaver and Lawton (2007: 1175) observed that definitions of eco-tourism tend to reflect a NorthSouth divide. From the South come definitions that privilege community-based models as well as conservation strategies and those from mainly Western countries focus on markets and institutions. Eco-tourism ventures should be viewed as more than businesses as noted by Muzvidziwa (2000: 58) "While profit is an important motivating factor for establishing eco-tourism projects, unlike ordinary tourism, there is a strong desire to offer a rewarding, rich, participatory experience involving the tourist and the host community". Beaumont (2001), note that ecotourism should take place in a natural setting, should be ecologically sustainable and must embrace environmental education or appreciation. Some definitions also include the principles of contributing to conservation and providing net benefits local communities. Kruger (2005) noted that community participation is the key dimension in eco-tourism ventures. This is something CAMPFIRE RDCs have successfully managed to bring onboard in Zimbabwe. One is tempted to agree with Scheyvens (1999) who underlines that ecotourism ventures should only be considered successful if local communities have some measure of control over them and if they share equitably in the benefits emerging from ecotourism activities. An empowerment framework should drive eco-tourism.

\section{Benefits of Ecotourism}

Behind such comprehensive definitions of ecotourism, like the ones adopted in this study 
are high expectations that eco-tourism would generate a wide variety of benefits. Associated benefits of ecotourism noted elsewhere but also applicable to Zimbabwe include the following:

- high quality tourism experiences;

- diversification of the economic base (Notzke 1999);

- creation of social benefits and infrastructure improvements (Brandon 1996);

- generation of funds for the management and conservation of natural areas (Weaver 1998);

- provision of economic justification for protection of natural resources (Boo 1990);

- fostering of environmental awareness/values and support for conservation, among both local residents and tourists, through on-site educational opportunities (Ross and Wall 1999); and

- promotion of cultural preservation (Slinger 2000).

\section{Eco-Tourism Experiences in Zimbabwe}

Following the setting up of a Government of National Unity in February 2009 the country reported a three percent positive growth of the tourism arrivals in 2009 (Xaba 2010). Tourist dollars rose from US\$294 to US\$523. The tourist arrivals and visitors numbered 2.5 million. MuirLeresche and Nelson (2001), describe Zimbabwe, Namibia, Botswana and South Africa as having improved conditions for both wildlife and people by giving greater control over wildlife to landowners-from large game ranchers to poor, rural communities. Integrating conservation with commercial activities has ensured viability in terms of the drive for wildlife eco-tourism. The Government of Zimbabwe (1998) reported that " 30 percent of Zimbabwe is under some form of wildlife management and it is the fastest growing sector and a major foreign currency earner in the national economy." However, today the greatest threat to early gains relating to wildlife management is politics.

The Zimbabwe Tourism Authority (ZTA), Central Statistics Office (CSO) records, and many other statutory bodies that keep statistics on the number of tourist arrivals in Zimbabwe do not disaggregate eco-tourists from other tourist categories. It is therefore tempting to conclude that the fluctuations in tourist arrivals also re- flect actually fluctuations in the number of those coming in as eco-tourists. However the main thrust of most tour operators and their use of the term eco-tourist experiences accompanied by an increase in the total number of international arrivals between 1980 and 1998 creates an impression that support the view that eco-tourist arrivals have also been increasing during this period. For instance, in 1980 the number of arrivals was 250000 rising to 1075573 in 1997. In Zimbabwe eco-tourism developments have been greatest in CAMPFIRE RDCs areas. For instance communities that are adjacent to National and Game parks such as Gonarezhou in Southern Zimbabwe, the Zambezi valley and other places endowed with wildlife have been allowed to tap this potential in terms of consumptive and nonconsumptive safari operations. This policy of allowing local communities to benefit from wildlife resources in National Parks resulted in dramatic declines in poaching and other illegal activities and a conscious need by local communities to conserve wildlife (Peterson 1991). Beside CAMPFIRE RDCs a number of conservancies mostly located in region IV and V, Zimbabwe's semi arid zones had sprouted up offering ecotourist experiences. Generally speaking conservancies had embraced eco-tourism as their driving force. Among the lead conservancies in this mould were Malilangwe and Save Valley Conservancies in the south eastern part of the country. Conservancies sought the establishment of ecologically and economically viable operations. Most of the conservancies were forging links with their communal neighbours. Such moves would result in local communities benefiting from eco-tourist ventures in the conservancies. For instance Malilangwe Trust's (1998) vision in terms of present and future developments in its handbook, committed the conservancy to work towards:

- The creation of an abundant wildlife population to support top quality eco-tourism ventures;

- Conservation of endangered species such as the black Rhino;

- Turning Zimbabwe's lowveld area into an internationally recognised tourist destination; and

- Building mutually beneficial linkages with neighbouring communal communities.

Stakeholders in the tourism sector had come to realise the importance of eco-tourism ven- 
tures. Eco-tourism could contribute towards the minimization of negative impacts on natural and cultural resources, direct revenue for the conservation of wildlife resources, and could ensure the direct flow of tangible benefits to local communities. Zimbabwe is trying to pursue a policy that puts emphasis on what one might refer to as 'low volume, high returns, and high quality tourism'. Eco-tourism developments show the importance of integrating and ensuring genuine participation of local communities.

The participation of local communities and the subsequent flow of benefits to these communities and emphasis on conservation differentiate eco-tourist ventures from other forms of tourism. In a detailed study concerning the state of eco-tourism in CAMPFIRE RDCs Muzvidziwa, Mamimine and Pangeti (1999) identified ecotourism projects that are

- located in communal lands but operated by communities and RDCs these included examples such as Sunungukai Camp near Mazoe river area;

- located in communal areas with access to National Parks but are run by private operators examples are Mahenye and Chilo lodges, Zambezi expedition et;

- run by private operators but located outside communal lands and linked to communal areas; and

- Conservancies.

At the time of writing this paper international tourist arrivals have slightly improved buoyed by the new found economic stability after a decade of economic turmoil. The Zimbabwe Tourism Authority was confident that once again Zimbabwe would regain its status as a leading tourist destination in Africa. The lifting of travel warnings and travel bans for their citizens by the USA, Japan, Germany and several western governments boosted tourists numbers visiting the country. In 2009 European visitors grew by 8400 to 45717 and tourists from the USA grew from 24000 to 28000 and a total of 30552 Asians visited the country. In the last decade the majority of the visitors came from Africa. However, the number of overseas visitors according to ZTA (2004) grew slightly in the past two years. The Zimbabwean Unity Governments pins its hope for an economic turnaround on the tourist industry which is expected to become a US\$1 billion dollar industry in the next five years. Bond (1997) observed differences in expenditure pat- terns between tourists depending where they came from. For instance North Americans spent between US\$2000 and US\$3000 per visit, while the average Zambian spent between US\$5 and US\$13 per visit. While the arrival figures do not disaggregate tourists according to sector, the information is useful as an indicator of the general performance of the tourism sector.

\section{Eco-tourism Potential in Zimbabwe}

Eco-tourism is both a conservation strategy as well as a developmental tool. Muzvidziwa et al. (1999), Child (1997) and many others have noted that Zimbabwe is full of eco-tourist attractions. The development of potential attractions offers an opportunity to develop eco-tourism to the full. Up until the onset of the 2000 land invasions, Zimbabwe was ranked the fourth most attractive tourist destination in Africa (WTO 1996). Willis and Pangeti (1998) observed that tourism was Zimbabwe's third highest foreign currency earner close behind mining and agriculture. Yet events in the post 2000 period have shown that this optimism was rather misplaced as tourism took a turn for the worse following the much publicised land invasions and land grab policies of the Mugabe government since 2000 . Tourism is very susceptible to political and social developments being experienced at the destination area. Zimbabwe has potentially exciting eco-tourism destinations, as a country it is endowed with natural, cultural and historical unique sites. Wildlife offers the greatest potential for eco-tourism. The many still to be developed attractions, offer a potential for developing a unique eco-tourist experience. For instance Willis and Pangeti (1998) and the ZTA (1997) identified potential eco-tourists attractions, activities and facilities that go along with a programme to develop the country's potential. Practically speaking every RDC has some ecotourist potential. Brandon (1995: 11) observed that sites with the greatest potential in terms of eco-tourism development needed to have the following attributes:

- wildlife that tourists can view, have greater accessibility and adequate infrastructure

- existence of a local culture that can offer tourists a lasting cultural experience

- economic competitiveness

- the need for aggressive marketing. 
In the lowveld circuit there is a wildlife corridor that connects with the trans-frontier conservation area linking Mozambique, South Africa and Zimbabwe. This could be developed to tape the enormous eco-tourism potential of the three countries. The riverine areas, the wilderness experience of hills, forests, birds, National Parks and the various cultures in the country offer an opportunity to develop this eco-tourism potential through activities such as photographic and game viewing, birding, consumptive tourism through hunting safari, fishing, walking safari, cultural tours/visits, and visits tom places of historic and archaeological interest. Eco-tourist development potential similarly exists in the northern circuit of the country. Transforming this eco-tourist potential into reality does demand putting in place (after the conduct of environmental impact assessments [EIAs] and viability studies) facilities such as lodges, chalets, camp sites, picnic sites, walking trails, concessions backed by a sound marketing plan. A co-ordinated approach is needed in order to achieve eco-tourism development. This will ensure that the various potential actors such as the private sector, local communities, donors, NGOs, government, local authorities and enterprising individuals collaborate and pull resources for the development of eco-tourism in the country.

Recent developments in Zimbabwe show that despite the potential for some time to come due to the prevailing political and economic climate not much will be achieved as investment in this sector might not be ploughed back into the economy. Many obstacles exist preventing the full realisation of the country's eco-tourism potential. Success depends on the country presenting a positive image to the outside world especially the western world. Not much seems to be happening as far as unpacking the negative image of Zimbabwe in the international media. There are problems emanating from the lack of harmonisation of the planning and development of eco-tourism. There is a danger of a situation where every operator or district, seek to develop ventures which others might be better at doing. What is needed is selective targeting when it comes to developing eco-tourist ventures, taking into account a particular place and operator's competitive edge. Other problems limiting eco-tourism development are a result of poor marketing strategies, a weakly developed infrastructure to support eco-tourism, low-levels in terms of market demand for eco-tourist products, stiff competition coming from other SADC countries such as South Africa, Botswana, and Namibia. This calls for regional collaborative eco-tourism ventures such as the transfrontier conservation area.

\section{CONSERVANCIES AND ECO-TOURISM}

\section{Defining Conservancies}

The term conservancy in Zimbabwe refers to a situation characterised by the amalgamation of a number of land and resource authorities into a single wildlife management unit. The Wildlife Working Group (WWW) (1994: 4) sees conservancies as representing "contractually based systems for the collective management of wildlife and other natural resources to achieve economies of scale and sustainability". Conservancies are therefore contractual units for the "communal co-management' of wildlife. 'CAMPFIRE is a common resources management programme for sustainable development by communal lands people who are empowered to decide how to manage their resources and benefit from the utilisation of these resources" (Peterson 1991: 5). CAMPFIRE sought to "initiate a programme for the long term development, management and sustainable utilisation of natural resources in communal areas ... involving forestry, grazing, water and wildlife" (Martin 1986: iv, 17). CAMPFIRE seeks to strengthen the capacity of local communities to use resources in a sustainable manner. CAMPFIRE put emphasis on the participation and sound application of conservation measures. Local communities were seen as key stakeholders as far as conservation and preservation of natural resources is concerned. Many conservancies such as Save Valley Conservancy (SVC), Malilangwe and several other conservancies in the southern lowveld in Zimbabwe have established links with their communal neighbours along CAMPFIRE lines.

Conservancies have created a local support base through the participation of local communities as well as the flow of benefits to such participating communities. Conservancies are comanaged for game viewing, hunting and photographic safaris. Ownership of the conservancy had to be vested in the community in which the resource is located. Zimbabwe has four types of 
land tenure system, namely private/commercial land (large and small-scale) these are on a freehold tenure system; resettlement lands a postindependence phenomenon driven by the desire to reduce land pressure and growing landlessness are on a leasehold tenure system; communal lands (the Rural District Councils [RDCs]) are based on an usufruct tenure system; and State land holdings (consists of mainly National Parks and selected wildlife areas, Forestry areas and State farms). Murphree and Metcalfe (1997) identified six conservancy typologies. The various typologies of conservancies show that it was possible that as co-management units RDCs and communal people could be persuaded to adopt the forms that best suited them. Through conservancies it was possible to develop wildlife supported eco-tourism ventures with local cultures forming the bedrock on which integrated rural development could be built. It was envisaged that the benefits flowing from such partnerships in the form of conservancies were going to enable local communities participate in job creation, poverty alleviation/reduction and improved infrastructure. Conservancies have not performed that well due to the chaotic land reform programme. However in some conservancies such as SVC wildlife populations have increased, elephants approximate 800 , there is a sizable herd of black Rhino and there is a large herd of antelopes plus many other species. Opportunities for local people include a rise in crafting and sculpturing activities, employment and selling of vegetables and fruits.

\section{CONSERVANCIES AND SUSTAINABLE DEVELOPMENT}

\section{Community Participation}

In times of crisis and great threats to sustainability and survival of wildlife local community interventions have come to the rescue of wildlife. Zimbabwe and a number of selected countries in the SADC region have given birth to innovative strategies of dealing with problems resulting from wildlife and people interactions. Resource based conflicts and rising levels of poverty, unemployment and landlessness have given rise as Barrow and Murphree (2001) observed to three forms of community conservation strategies. The three forms are: a) Protected area outreach, this seeks to enhance the biological integrity of national parks by working to educate and confer benefits on local communities. This is the model mainly adopted in Tanzania and places like Kruger National Park South Africa.

b) Collaborative management aims at creating agreements between local communities or resource users and conservation authorities for negotiated access to natural resources usually controlled by some statutory authority, lessons from Uganda are a case in point.

c) Community-based conservation, leads to the sustainable management of natural resources through devolution of control of for instance wildlife resources to the community as in the case of CAMPFIRE and Conservancies. This approach has been readily adopted in Zimbabwe.

Community conservation of wildlife resources has become a buzzword in Zimbabwe. Zimbabwe has the experience of successfully devolving authority and responsibility for wildlife first in the $1960 / 70$ s to private farmers then later mostly in the 1980/90s to selected local communities. According Barrow and Murphree (2001), community conservation of wildlife resources rests on four conceptual foundations namely:

1. Economic instrumentalism based on sustainable use of wildlife this confers high economic value on wildlife and is linked to the desire to see an improvement of the quality of life of a given community.

2. Devolution meant the conferment of authority and responsibility for wildlife resources to land owners and communities where these resources are found. This approach has led to a drastic decline in the wanton destruction of wildlife in Zimbabwe.

3. Policy shifts that allowed collective proprietorship and extending proprietorship rights over wildlife to private landowners. In Zimbabwe CAMPFIRE districts and conservancies were the major beneficiaries of such policy shifts.

4. Adoption of adaptive management principles as far as wildlife conservation is concerned. Zimbabwe had seen the adoption of an approach to wildlife conservation and policy that is dynamic and allows for inno- 
vative compromises to be embraced at the level of implementing programmes and policies on wildlife conservation.

There is no doubt that the set up of conservancies and their link to communal areas in countries like Namibia and Zimbabwe has been widely held as a success story (Child 1995; Metcalfe 1994; Turner 1996 and Barrow and Murphree 2001). Conservancies and CAMPFIRE in Zimbabwe received a lot of attention and were considered a successful story to the extent of being toyed around as the cornerstone of a sustainable eco-tourism development strategy. The greatest threat as far as their viability is concerned has turned out to be political processes especially the chaotic and violent land reform programme underway in Zimbabwe since 2000. Some of the constraints impacting on successful implementation of community conservation eco-tourism projects include

1. devolution of revenue appropriation though benefiting producer communities has been stalled at local authority level

2. the politics of resource appropriation has undermined the potential for greater achievements that could have accrued to those communities involved in wildlife management.

3. Compartmentalization in legislation and agency responsibility as CAMPFIRE and conservancies has shown that laws regulating wildlife management are de-linked from those regulating forestry, fisheries and water resources. This is a bottleneck limiting success as far community conservation of resources is concerned.

4. imposition of pre-existing administrative boundaries and land units can function to limit eco-tourism developments. The various land authority units linking up to form conservancies is another way of overcoming barriers imposed by these land traditional administrative boundaries. Trans-frontier conservation areas are another way of increasing sustainability and viability of wildlife management across national borders.

5. Devolution through persuasion rather than statute can easily falter when it comes under pressure in situations where there is the breakdown of the rule of law such as the case in Zimbabwe.

6. Differential contexts of economic incentives to conserve wildlife resources.
Availability of wildlife as a livelihood resource varies from one community to another hence the conflict between conservancies and their communal neighbours at one time and recently in Zimbabwe. The post 2000 era in Zimbabwe shows that it is easy to scuttle all the gains resulting from sound economic management of wildlife resources by local communities if politics is allowed to take a dominant role.

\section{Sustainability Issues}

Conservancies are still at an infancy experimental level but have shown the will and capacity to act as both conservation and investment business units where local communities are copartners and co-beneficiaries. This is vital for future sustainability. There is hope even though the conservancies have not passed the sustainability phase, that with improved socio-economic environment this should be possible. Devolution and stewardship of wildlife and other resources should go hand in hand (Murombedzi 1999). Two issues raised by Nemarundwe (2005) of interest to viability of conservancies is firstly the need to devolve natural resource management to levels below the local government RDC authorities and the need to initiate a process of local-level monitoring of natural resources and programmes.

\section{CONCLUSION}

One would like to believe that the current problems affecting wildlife utilisation and management in Zimbabwe are but a passing phase albeit a very painful one. Concepts do have different meanings and have a bearing on what people do. In Zimbabwe sustainability of ecotourist ventures is linked to use and attempts to conserve resources by giving them a use value. In a situation of poverty local communities can begin to regard wildlife in a positive light when they begin to derive benefits from such wildlife resources as what happened in CAMPFIRE RDCs. The major cause for lack of sustainability of wildlife driven tourism ventures like conservancies is mostly due to the unpredictable nature of politics. Eco-tourism development demands greater co-ordination of activities and commitment on the part of governments, communities and tourists. 
In conclusion one observes that despite the political crisis, which has generated social and economic instability threatening the viability of the once vibrant wildlife driven eco-tourism ventures in conservancies, these ventures continue to survive against odds. Conservancies in Zimbabwe show that it is not enough to have an abundance of natural resources in the face of socio-economic and political instability it is hard to achieve sustainable and successful development. Yet despite the setbacks there is evidence of the resilience of these community-based wildlife conservation ventures and strategies. In the long term maybe the only way eco-tourism can move forward in Zimbabwe is through the promise of a community-based wildlife driven ecotourism development strategy where there is truly devolution of power to local level institutions below the RDCs through ventures like conservancies. Despite the existing challenges threatening viability, conservancies seem to have withered the storm and might soon reclaim their place as viable sustainable eco-tourism ventures. The reaction of local communities, employees and the various stakeholders other than the ruling elite and senior Party officials with regard to conservancies is encouraging. People have not lost interest and hope. Despite the structural and legal constraints conservancies have been able to break even and local communities have continued to draw benefits. Conservancies give hope to Zimbabwe's future as tenurial units that will contribute to conservation efforts through utilisation of natural resources in a sustainable way ensuring use by future generations.

\section{REFERENCES}

Barnes JI, Schier C, van Rooy G 1999. Tourist's willingness to pay for wildlife viewing and wildlife conservation in Namibia. South African Journal of Wildlife Research, 29: 101-134.

Barrow E, Murphree M 2001. Community conservation. In: D Hulme, N Murphree (Eds.): African Wildlife and Livelihoods: The Promise and Performance of Community Conservation. Oxford: James Currey.

Beaumont N 2001. Ecotourism and the conservation ethic: Recruiting the uninitiated or preaching to the converted? Journal of Sustainable Tourism, 9(4): 314-341.

Bond I 1997. Tourism and sport hunting in Zimbabwe: A summary of current status, potential and constraints. In: DHM Cumming, TJP Lynam (Eds.): Land Use Changes, Wildlife Conservation and Utilisation, and the Sustainability of Agro-ecosystems in the Zambezi Valley, Final Technical Report. Harare: WWF Programme Office, 1-34.

Bond I. CAMPFIRE and the INCENTIVES for institutional change. In: D Hulme, M Murphree (Eds.): African Wildlife and Livelihoods: The Promise and Performance of Community Conservation. Oxford: James Currey, pp. 667-681.

Boo E 1990. Ecotourism: The Potentials and Pitfalls. Volume 1 and 2. Washington, DC: WWF.

Brandon K 1995. Eco-tourism Partnership. Manual from Latin American and the Caribbean. Arlington: The Nature Conservancy Publishers.

Björk P 1997. Marketing of Finnish eco-resorts. Journal of Vacation Marketing, 3(4): 303-313.

Bjork P 2000. Ecotourism from a conceptual perspective, an extended definition of a unique tourism form. International Journal of Tourism Research, 2: 189-202.

Central Statistics Office 2004. Monthly Migration Statistics. Harare: CSO.

Child GFT 1995. Wildlife and People: The Zimbabwean Success: How the Conflict Between Animal and People Became Progress for Both. Harare: Wisdom Foundation.

Chaminuka P, Groeneveld RA, Selomane AO, van Ierland EC 2011. Tourist preferences for ecotourism in rural communities adjacent to Kruger National Park: A choice experiment approach.Tourism Management, DOI: 10.1016/j.tourman. 2011. 02.016.

Duff N 2006. The politics of ecotourism and the developing world. Journal of Ecotourism, $5(1$ and 2): $1-6$.

Gossling S 2000. Tourism a sustainable development option? Environmental Conservation, 27: 223-224.

Government of Zimbabwe 1975a. National Parks and Wildlife Act. Harare: Government Printers.

Government of Zimbabwe 1975b. Zimbabwe Communal Lands Act. Harare: Government Printers.

Kruger O 2005. The role of ecotourism in conservation: Panacea or Pandora's box? Biodiversity and Conservation, 14: 579-600.

Lashley C, Lynch P, Morrison A (Eds.) 2007. Hospitality: A Social Lens. Oxford: Elsevier.

Malilangwe Conservation Trust 1998. Annual Report. Chiredzi: MCT.

Martin RB 1986. Communal Areas Management Programme for Indigenous Resources. Harare: DNPWM

Meletis ZA, Campbell LM 2007. Call it consumption! Reconceptualising eco-tourism as consumption and consumptive. Geography Compass, 1(4): 850-870.

Metcalfe S 1994. The Zimbabwe Communal Areas Management Programme for Indigenous Resources (CAMPFIRE). In: D Western, RM Wright (Eds.): Natural Connections: Perspectives in Communitybased Conservation. Washington DC: Island Press, pp.161-192.

Mmopelwa G, Kgathi D L, Molefhe L 2007. Tourists' perceptions and their willingness to pay for park fees: A case study of self-drive tourists and clients for mobile tour operators in Moremi Game Reserve, Botswana. Tourism Management, 28(4): 1044-1056.

Mowforth M, Munt I 1998. Tourism and Sustainability: New Tourism in the Third World. London: Routledge. 
Muir-Leresche K, Nelson R H 2001. The Southern African Experiment. Centre for Private Conservation's Study Private Property Rights to Wildlife:

Murombedzi J C 1999. Devolution and stewardship in Zimbabwe's CAMPFIRE Programme. Journal of International Development 11: 287-293.

Murphree M, Metcalfe SC 1997. Conservancies, Policy and CAMPFIRE Programme in Zimbabwe. Harare: CASS.

Muzvidziwa VN 2000. Eco-tourism and the human factor in Zimbabwe. Review of Human Factor Studies, 6(2): 57-76.

Muzvidziwa VN, Mamimine PW, Pangeti G 1999. The State of Eco-tourism in Zimbabwe's CAMPFIRE Districts. Harare: Centre for Applied Social Sciences, University of Zimbabwe.

Nemarundwe N 2005. The performance of CBNRM in the face of socio-political dynamism: A case study of CAMPFIRE in Mosaka, Zimbabwe. In: V Dzingirai, C Breen (Eds.): Confronting the Crisis in Community Conservation: Case Studies from Southern Africa. Centre for Environment, Agriculture and Development University of Kwazulu-Natal, pp. 243-264.

Notzke C 1999. Indigenous tourism development in the Arctic. Annals of Tourism Research, 26(1): 5176.

Peterson JH 1991. CAMPFIRE: A Zimbabwean Approach to Sustainable Development and Community Empowerment through Wildlife Utilisation. Harare: CASS.
Ross S, Wall G 1999. Ecotourism: Towards congruence between theory and practice. Tourism Management, 20(1): 123-132.

Saayman M, Saayman A 2009. Why travel motivation and socio-demographics matter in managing a national park. Koedoe, 51(1): 381-390.

Scheyvens R 1999. Ecotourism and the empowerment of local communities. Tourism Management, 20: 245-249.

Sirakaya E, Sasidharan V, Sönmez S 1999. Redefining ecotourism: The need for a supply-side view. Journal of Travel Research, 38: 168-172.

Slinger V 2000. Ecotourism in the last indigenous Caribbean community. Annals of Tourism Research, 27(2): 520-523.

Turner S 1996. Conservancies in Namibia: A Model for Successful Common Property Resource Management? Windhoek: Social Sciences Division, Centre for Multi-disciplinary Research, University of Namibia.

van der Merwe P, Saayman M 2008. Travel motivations of tourists visiting Kruger National Park. Koedoe, 50(1): 154-159.

Weaver D 2001. Ecotourism. Milton: John Wiley and Sons Publishers.

Weaver D B, Lawton L J 2007. Progress in tourism management twenty years on: The state of contemporary eco-tourism research. Tourism Management, 28: 1168-1179.

Wildlife Working Group 1996. Report on the Wildlife Working Group. Mutare: WWG. 